\title{
Ethnic Entrepreneurship In OECD Countries: A Systematic Review Of Performance Determinants Of Ethnic Ventures
}

\author{
Maxime Legros, Laval University, Canada \\ Egide G. Karuranga, Laval University, Canada \\ Marie-France Lebouc, Laval University, Canada \\ Muhammad Mohiuddin, Laval University, Canada
}

\begin{abstract}
This paper seeks to examine the evolution of determinants under scrutiny by academics publishing on performance of ethnic companies in Organisation for Economic Co-operation and Development (OECD) countries. Using the systematic literature review method, we first provide a descriptive analysis of articles gathered, and then make an in-depth examination of the determinants focused on. A database of 40 papers published between 2002 and 2011 was collected - the topic was precise enough to yield only a few articles - from a wide range of journals. We provide a systemized summary of the current status of this body of work, examine areas where research is lacking, and explain why further study of the role of cultural and ethical values as determinants of ethnic entrepreneurship is critical.
\end{abstract}

Keywords: Ethnic Entrepreneurship; Skilled Immigrants; Performance; Innovation; Creativity; Human Capital; Social Capital; Moral Values

\section{INTRODUCTION}

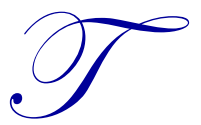

he War for Talents (McKinsey \& Company, 2001) - a competitive landscape for recruiting and retaining talented employees - within the Organization for Economic Co-operation and Development (OECD) member states, is a global trend that every country and company has to face nowadays. This trend is worsening with population ageing. De facto, the challenge is to attract and retain the most able and talented employees from a skilled workforce that is becoming increasingly narrower. The brain drain (Royal Society, 1963) or large-scale emigration of individuals with technical skills or knowledge to a more attractive country - only exacerbates the growing scarcity of talented manpower in home country. The distribution of this skilled manpower worldwide is extremely unequal since only two countries account for around 50\% of the main OECD destinations of OECD-born highly-skilled expatriates: the United States (37.1\%) and Australia (12.7\%) (OECD, 2008).

The resulting diversity is not only an asset making it possible for companies to "fill in the blanks" but also to create value within the organization. A recent wave of researchers has indeed wondered if workplace diversity does not represent a competitive advantage for firms (Slater, Weigand, \& Zwirlein, 2008). Studies now consider that multicultural teams can enhance performance (Roberge \& van Dick, 2010; Sultana, Rashid, Mohiuddin, \& Mazumder, 2013), innovation (Ostergaard, Timmermans, \& Kristinsson, 2011) or creativity (Berg \& Holtbrügge, 2010) for companies. In other words, it is increasingly clear that diversity benefits the groups it affects. Immigrants and ethnic workers are not to be feared but rather sought after because the cultural "cross-pollination" they engender promotes performance. It is with this hypothesis in mind that other researchers have started investigating the impact of immigrant and ethnic entrepreneurs on their ethnic and host communities. Thus, according to Fainstein "the competitive advantage of cities, and thus the most promising approach to attaining economic success, lies in 
enhancing diversity within the society, economic base, and built environment" (Fainstein, 2005). However, immigrant and ethnic entrepreneurship is a rather recent trend in entrepreneurship studies.

The present paper aims at understanding what determinants of ethnic and immigrant entrepreneurship have been studied so far, what types of performance it can lead to, and what areas are still lacking rigorous investigation. Ethnic and immigrant entrepreneurships, which will be shortened below as "ethnic entrepreneurship", may offer insights into what alternative business models are more suited nowadays to face social and economic challenges. In order to attain this objective, a systematic review was used. Systematic reviews are empirical designs that allow assessing and analyzing existing researches on a given topic in a methodical and replicable way (Staples \& Niazi, 2007). A systematic review is a summary of research that uses explicit methods to perform a thorough literature search and critical appraisal of individual studies to identify the valid and applicable evidence (Mohiuddin, 2011). This paper will first present the overall review process and the adopted review protocol in section two. Then, we will describe results from the review in section three. Only then will we discuss and analyze the findings in section four and continue towards the conclusion in section five with the future avenue of research on Ethnic entrepreneurship.

\section{SYSTEMATIC REVIEW METHODOLOGY}

The methodology for a systematic review has to be clear and accurate, since a literature review "must be defined by a guiding concept [...]. It is not just a descriptive list of the material available or a set of summaries" (Taylor \& Procter, 2008). Hence in order to build the most suitable set of articles, we followed the following procedure: We started with a broad prospection of articles; then we went to a couple of steps in which we first assessed the content of articles retrieved and secondly refined the selection criteria. We reiterated these two steps as long as we were unsatisfied with the match between our research objective and the articles we found. This procedure is detailed below. We used four databases to create our systematic review: Emerald, Engineering Village, ProQuest and Science Direct. We covered a 10-year time period, from January 2002 to the end of September 2011. The search for articles took place from 09/22/2012 to 10/16/2012. The very first step of our research was to gather as many articles as possible. For that reason we used a broad taxonomy described in Table 1. When it was possible, we selected the tab "journals" (i.e. for Emerald and Science Direct), in order to achieve coherence in the results.

Table 1: Taxonomy of the Preliminary Research

\begin{tabular}{|l|l|l|}
\hline \multicolumn{2}{|c|}{ Search with Keywords } \\
\hline Theme & $\begin{array}{l}\text { "Ethnic entrepreneurship" OR "Immigrant } \\
\text { entrepreneurship"" }\end{array}$ & $\begin{array}{l}\text { "Abstract" (Em.); "Subject/title/abstract" (Eng.); } \\
\text { "Citation \& abstract" (Pro.); "Abstract" (Sc.)* }\end{array}$ \\
\hline And & Creativity OR Innovation OR Performance & $\begin{array}{l}\text { "All fields" (Em.); "Subject/title/abstract" (Eng.); } \\
\text { "Citation \& abstract" (Pro.); "All fields" (Sc.) }\end{array}$ \\
\hline Pdn & $>01 / 01 / 2002<09 / 30 / 2011$ & \\
\hline
\end{tabular}

*Em.: Emerald; Eng.: Engineering Village; Pro: ProQuest; Sc.: Science Direct

We obtained a very large sample with this first strategy as, indeed, we retrieved 3,292 articles. A brief glance at those results showed us that Science Direct yielded the greatest number of responses. Moreover, this preliminary research helped us determine that the most efficient query was the Boolean combination of "ethnic entrepreneurship" AND "performance" since it returned 33\% of our initial sample. Following more refining of the articles based on abstract readings, we selected 140 articles. Graph 1 shows the repartition of that second sample across the four databases. 


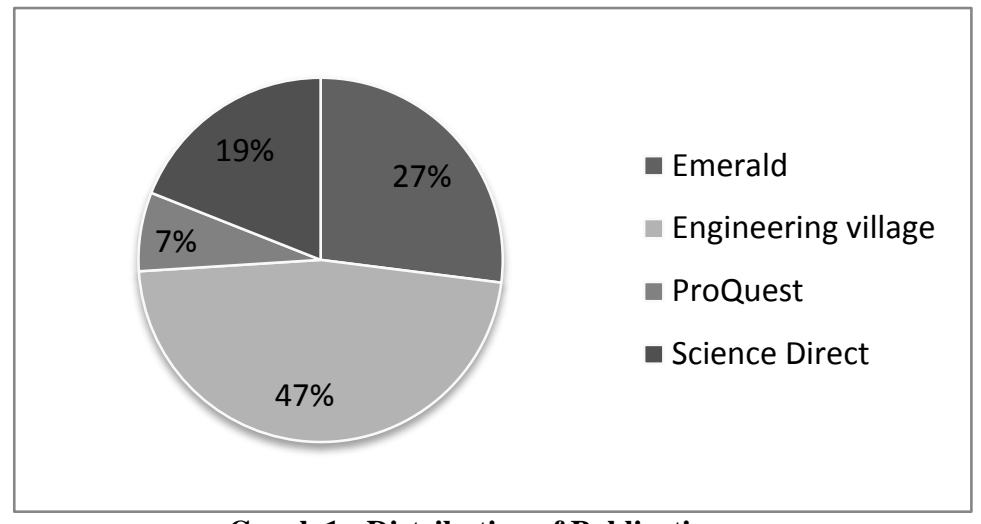

Graph 1: Distribution of Publications

We can have the overview of refining process of articles from the following Table 2.

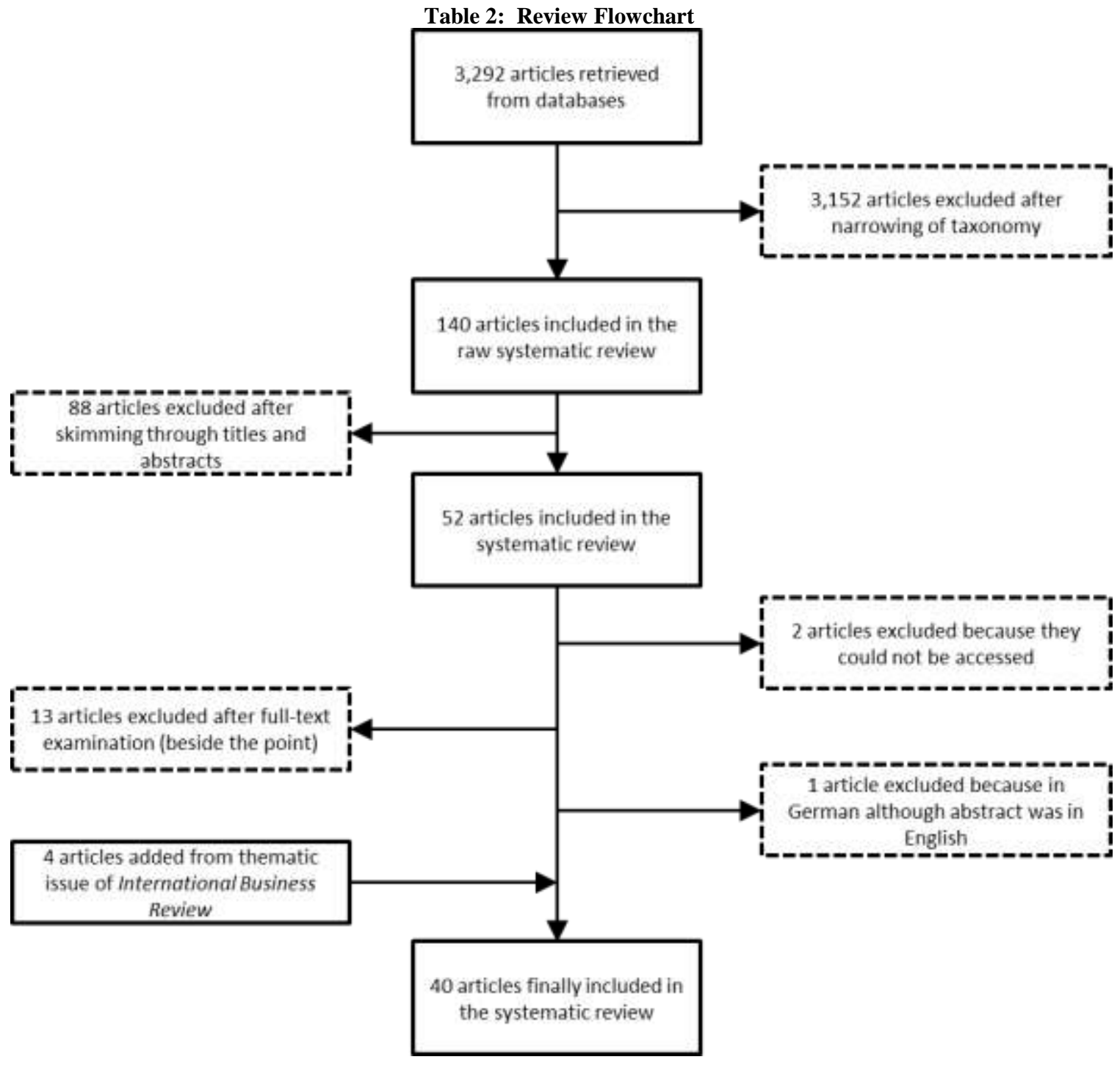




\section{DESCRIPTION OF RESULTS}

The aim of the present section is to describe the global characteristics of the 40 articles gathered through general categories, as should be done in every systematic review (Tranfield, Denyer, \& Smart, 2003). Hence, we will first analyze the countries and communities that were most studied (1), then the adopted research methodology (2), the publication titles and time-based trend of publication (3), and lastly the scope of analysis of each article (4).

\subsection{Countries and Communities Studied}

As we are focusing on ethnic entrepreneurship, it is necessary to highlight which communities in which countries are the primary interest of authors. Some countries and some communities will be more studied because of immigration policies or of entrepreneurial willingness embedded in ethnic communities' cultural values. Unsurprisingly, the USA is the most studied host country, as shown in Table 3. Ethnic businesses represent over 17\% of all American small business in 2005 (United States Census Bureau, 2010; Shinnar, Aguilera \& Lyons, 2011). It is therefore an ideal ground for researching ethnic entrepreneurship.

Table 3: Countries Studied in Publications

\begin{tabular}{|c|c|c|c|c|}
\hline Regions & Countries & \multicolumn{2}{|c|}{ Publications } & Percentages \\
\hline Asia & $\begin{array}{l}\text { China } \\
\text { Japan }\end{array}$ & $\begin{array}{l}1 \\
1\end{array}$ & 2 & $4.4 \%$ \\
\hline Europe & $\begin{array}{l}\text { Belgium } \\
\text { Germany } \\
\text { Greece } \\
\text { Netherlands } \\
\text { Turkey } \\
\text { UK } \\
\text { Ukraine } \\
\end{array}$ & $\begin{array}{l}1 \\
4 \\
1 \\
4 \\
1 \\
5 \\
1 \\
\end{array}$ & 17 & $38 \%$ \\
\hline Near/Middle East & Israel & 1 & 1 & $2.2 \%$ \\
\hline North America & $\begin{array}{l}\text { Canada } \\
\text { USA }\end{array}$ & $\begin{array}{c}6 \\
13 \\
\end{array}$ & 19 & $42 \%$ \\
\hline Oceania & Australia & 2 & 2 & $4.4 \%$ \\
\hline None especially & & 4 & 4 & $8.8 \%$ \\
\hline Total & & 45 & 45 & $100 \%$ \\
\hline
\end{tabular}

Table 4: Communities Studied in Publications

\begin{tabular}{|c|c|c|c|c|}
\hline Regions & Communities & \multicolumn{2}{|c|}{ Publications } & Percentages \\
\hline Africa & $\begin{array}{l}\text { Middle/South African } \\
\text { North African }\end{array}$ & $\begin{array}{l}3 \\
2\end{array}$ & 5 & $8 \%$ \\
\hline Asia & $\begin{array}{l}\text { Chinese } \\
\text { Indian } \\
\text { Korean } \\
\text { Pakistani } \\
\text { Others }\end{array}$ & $\begin{array}{l}4 \\
3 \\
2 \\
2 \\
6\end{array}$ & 17 & $28 \%$ \\
\hline Europe & $\begin{array}{l}\text { Former USSR } \\
\text { Turkish } \\
\text { Others }\end{array}$ & $\begin{array}{l}2 \\
4 \\
4\end{array}$ & 10 & $6 \%$ \\
\hline Near/Middle East & $\begin{array}{l}\text { Bangladeshis } \\
\text { Others }\end{array}$ & $\begin{array}{l}2 \\
2 \\
\end{array}$ & 4 & $7 \%$ \\
\hline Latin America & Others & 6 & 6 & $10 \%$ \\
\hline North America & American & 1 & 1 & $1.6 \%$ \\
\hline Ethnic at large & & 18 & 18 & $30 \%$ \\
\hline Total & & 61 & 61 & $100 \%$ \\
\hline
\end{tabular}

On the contrary, when it comes to communities, there is no strong superiority of one ethnicity over another. Authors usually consider specific ethnic groups in each country. For instance, people of Chinese and Turkish origins are analyzed slightly more often, as explicated in Table 4. Indeed, both ethnic groups present a higher rate of entrepreneurship than the national average of their various host countries. For instance, in the UK, 35\% of Turkish- 
born residents own their own businesses compared to just 13\% of all UK nationals (Altan, 2007; Altinay \& Altinay, 2008).

The spectra of analysis for host countries and ethnic communities are also interesting to observe. It appears that, notwithstanding the countries or ethnic communities studied, the most common research design focuses on a single host country within which several ethnic communities are analyzed. Furthermore, it is striking to note that most authors don't take into account any specific ethnic group at all. They choose what we called the "ethnic at large" approach (see far right bar in Graph 2), that is to say authors include ethnic entrepreneurs in their respondents regardless of which ethnic community they come from. Therefore, these researchers forgo cultural explanations of entrepreneurial rates.

\subsection{Main Research Methodologies in Ethnic Entrepreneurship Research}

As depicted in Graph 2, the research methodology mainly chosen by authors is the use of secondary quantitative data, with a total of 14 articles out of 40 . Government surveys or national censuses are the most useful sources for authors who have limited resources (money or time). Close behind, collecting primary qualitative data is the second favorite methodology with 12 articles: Most authors prefer face-to-face interviews to develop a deeper analysis. Finally, theoretical approaches are used in eight articles to present and support new frameworks or develop new hypotheses.

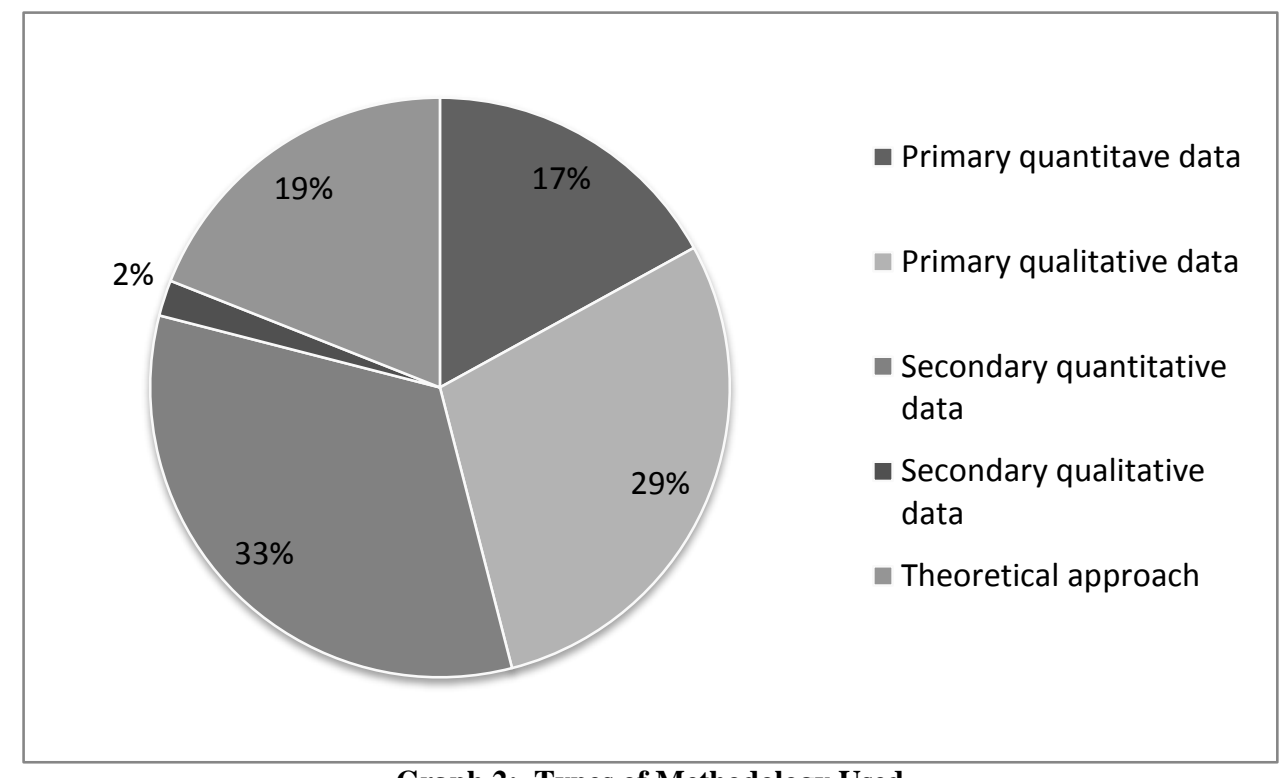

Graph 2: Types of Methodology Used

\subsection{Distribution across Publication Titles and Time-Based Trend of Publication}

The distribution of articles across peer-reviewed journals is scattered across the business and management research streams considering the global scope of our research. There is no clear domination of one publication over the others - the one with the highest number of retained articles is International Business Review but it accounts for only five articles out of 40 . Our systematic sample of 40 articles is divided between 28 different journals. This assessment shows how the subject is studied from very different angles by different authors with specific concerns.

As for the time-based trend of publication, Graph 3 indicates a growing interest in the literature. The year 2011 alone represents $33.3 \%$ of all the articles we retrieved. Authors as well as governments start to take the subject of ethnic entrepreneurship into consideration because of the economic growth and regeneration of economies it leads to (Assudani, 2009; Chand \& Ghorbani, 2011). 


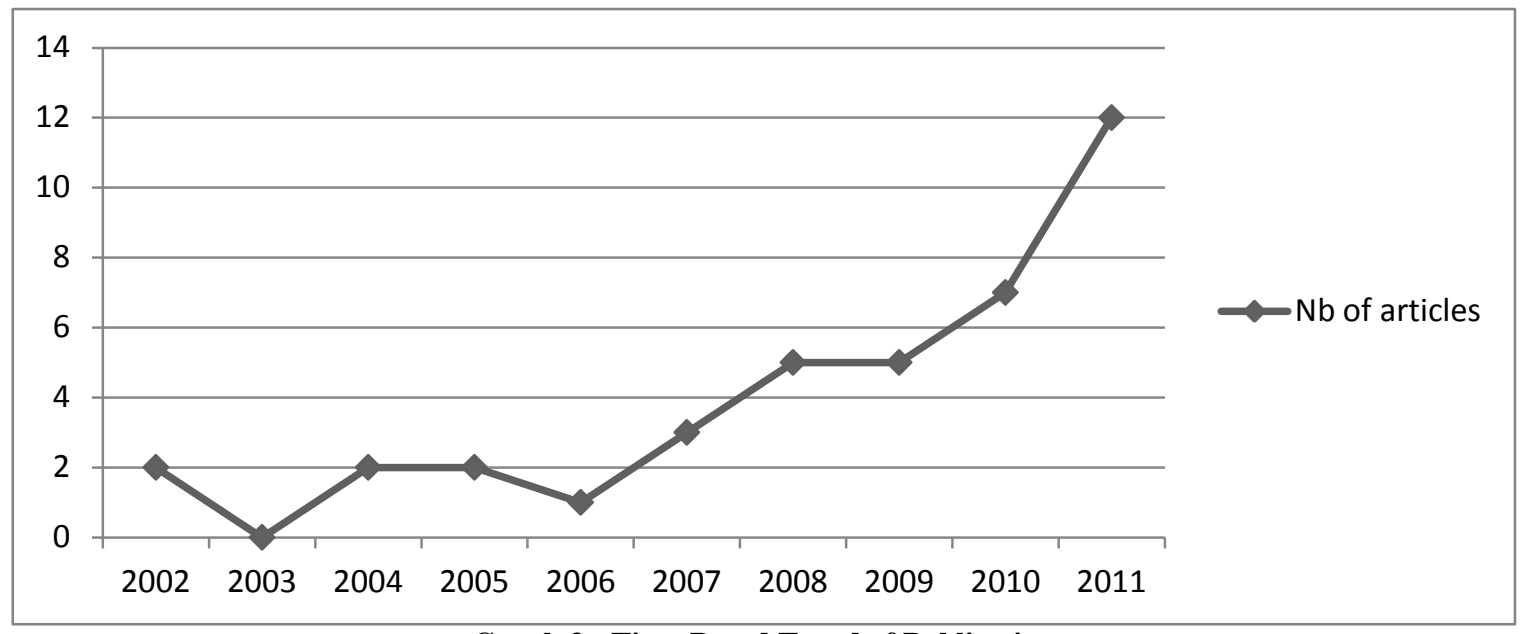

Graph 3: Time-Based Trend of Publication

\subsection{Scope of Analysis}

When authors tackle the subject of entrepreneurship, they have to decide at what level they wish to situate their analyses. Will they focus on individual decisions, organizational culture, ethnic community values in general, or external factors such as host government favorable measures as a determinant for ethnic entrepreneurial success? In other words, will they view it from the individual, organizational, community or country level? The level or scope of analysis is a key choice since it will impact the entire orientation of the study. Indeed it concerns every step of the process of entrepreneurship from the reasons for launching a business to the final performance measure of the venture.

Graph 4 reveals that individual actions are the most analyzed facet of the entrepreneurship process and refer mainly to the social, human and economic capital that immigrants will use (Curci \& Mackoy, 2010; Masurel, Nijkmamp, Tastan, \& Vindigni, 2002; Siqueira, 2007). Community values arrive in second position and the entrepreneurial performance of an entire ethnic group, for example African-American (Bogan \& Darity, 2008), are discussed. Authors with a focus at the organizational level choose to scrutinize the market targeted by ethnic entrepreneurs and the general strategy they adopt, either aiming at co-ethnic consumers or opening up to a broader, national or dominant, market. Noticeably in our sample, the latter authors predominantly analyzed ethnic businesses that remained in enclave markets (see Graph 5) and only one focused on the opening from ethnic, to dominant markets.

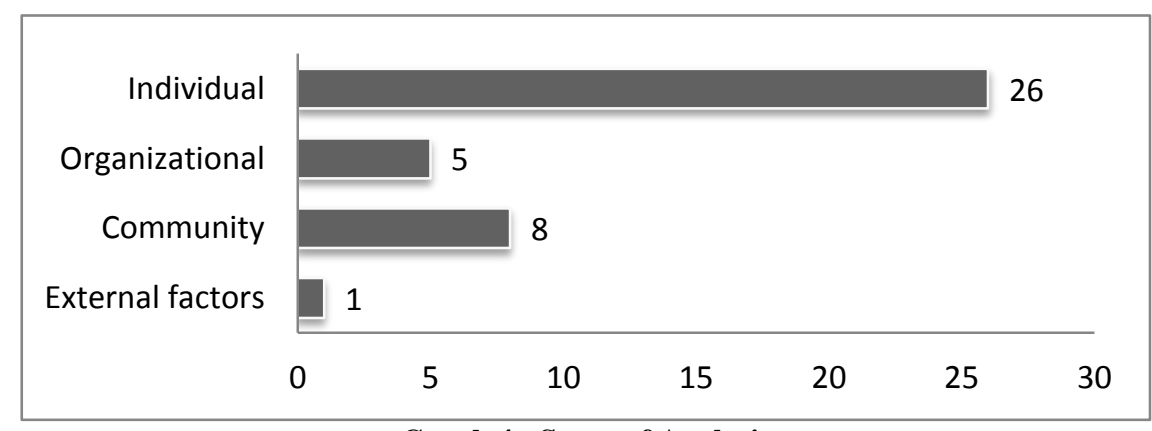

Graph 4: Scope of Analysis 


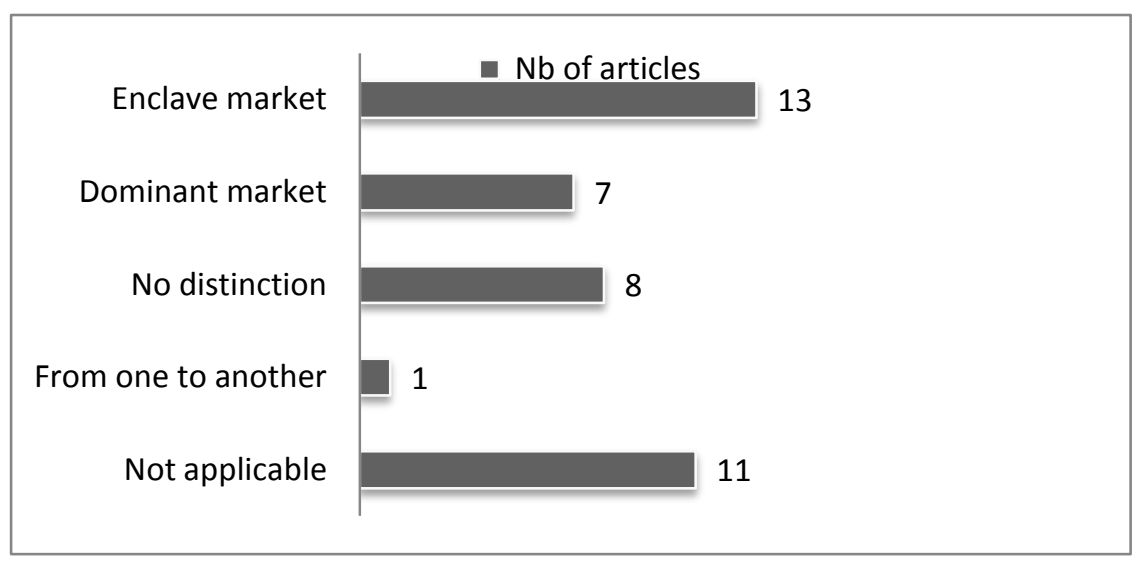

Graph 5: Markets Targeted by Ethnic/Enclave Entrepreneurs

\section{DISCUSSION OF FINDINGS}

We will now proceed with an analytical examination of the results described above with regard to our initial research objective, which was to highlight the determinants of performance for ethnic companies in OECD countries. We will take advantage of this discussion to put forward a few observations with regard to dominant traits of literature and possible improvements. Our understanding of performance agrees with that of Sahin, Nijkamp, and Stough (2011):

"In our study, business performance refers to the objective criteria: market share, turnover and profitability (e.g., net and gross profit). Besides these variables, we also included internal and external success factors, or attributes, such as productivity, costs, stability, growth, business culture, reliability, market knowledge, employees, quality, price, innovation, products, etc. in order to measure the business performance of migrant entrepreneurs." (Sahin, Nijkamp, \& Stough, 2011)

In our subsequent discussion of which elements affect the global performance of an ethnic company, we will resort to the basic segmentation between qualitative and quantitative indicators. Generally, quantitative indicators are used for the economic measure of the company's performance, whereas qualitative indicators are favored when it comes to presenting which elements induce that performance. Though there are some advantages to using only financial indicators for performance studies, they are considered as historical and "backward-looking" (Mohiuddin and Su, 2013). Sole reliance on current, financial measures of performance does not arguably reflect the importance of current resource decisions for future financial performance (Malina, 2013). They excessively reward short-term or incorrect behavior (gamesmanship and data manipulation) that may cause management frustration and resistance (Verbeeten and Boons, 2009). As a result, they are generally incongruent with the strategic goals of the organization (Atkinson et al., 1997).

We will start with (1) quantitative indicators for the presentation of performance measurement - accounting for $25 \%$ of the articles. We will then deal with qualitative indicators in the following order: (2) social capital determinants, (3) human capital determinants and (4) innovation determinants - respectively accounting for $29 \%$, $26 \%$ and $11 \%$ of the selected articles. Residual determinants like host environment or economic capital represent only $9 \%$ of articles and will not be treated here. However, we will discuss the surprising absence of (5) axiological determinants, or the impact of the entrepreneur's moral values on the performance of his/her venture. The relative importance of each type of determinants in the sample under review is presented in Graph 6 below. 


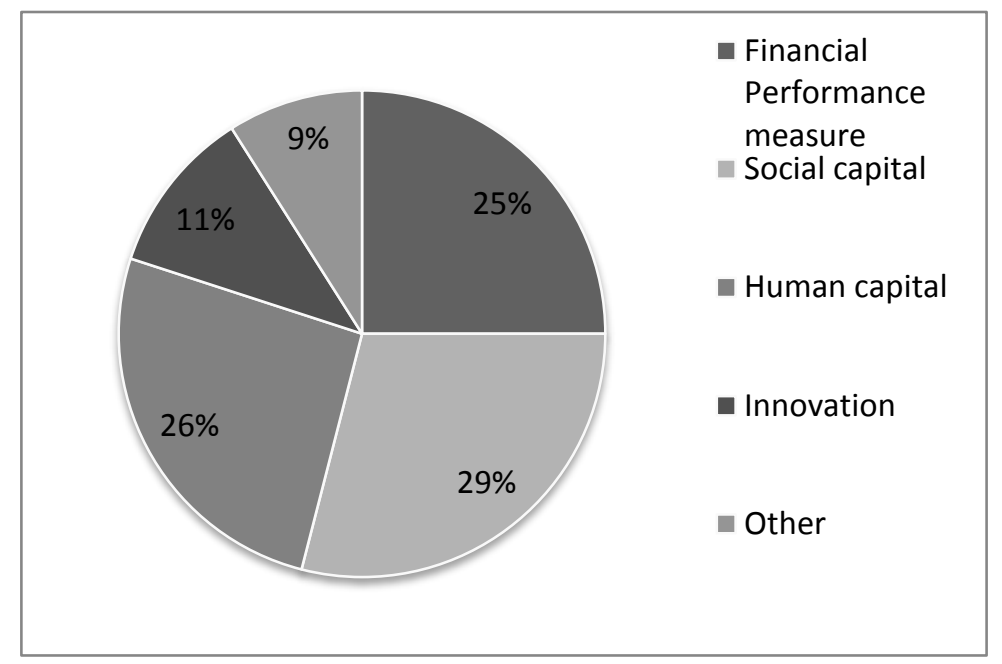

Graph 6: Relative Importance of Each Type of Indicators

\subsection{Performance Measurement}

When it comes to the measurement of performance, the articles we selected provide two types of information: the level at which performance is felt and what exactly is measured in terms of performance. A quarter of the articles we selected tackle only the impact of performance and at which level it is to be measured. For Masurel, Nijkmamp, Tastan, and Vindigni (2002), "the collective creation of value is a preferred measure of success." Indeed, 56\% of selected articles deal with the entire ethnic company's performance. In contrast, only $25 \%$ refer to the sole performance of the ethnic entrepreneur, such as access to stable employment or a higher wage (Constant, 2009; Constant \& Shachmurove, 2006). Even fewer articles, 13\%, consider performance of a whole ethnic group as entrepreneurs (Georgarakos \& Tatsiramos, 2009; Wang \& Li, 2007). Finally, only one article deals with the impact of ethnic entrepreneurship on the host society's performance (Eraydin, Tasan-Kok, \& Vranken, 2010). Graph 7 presents a summary of the distribution of articles according to the level of the impact measured.

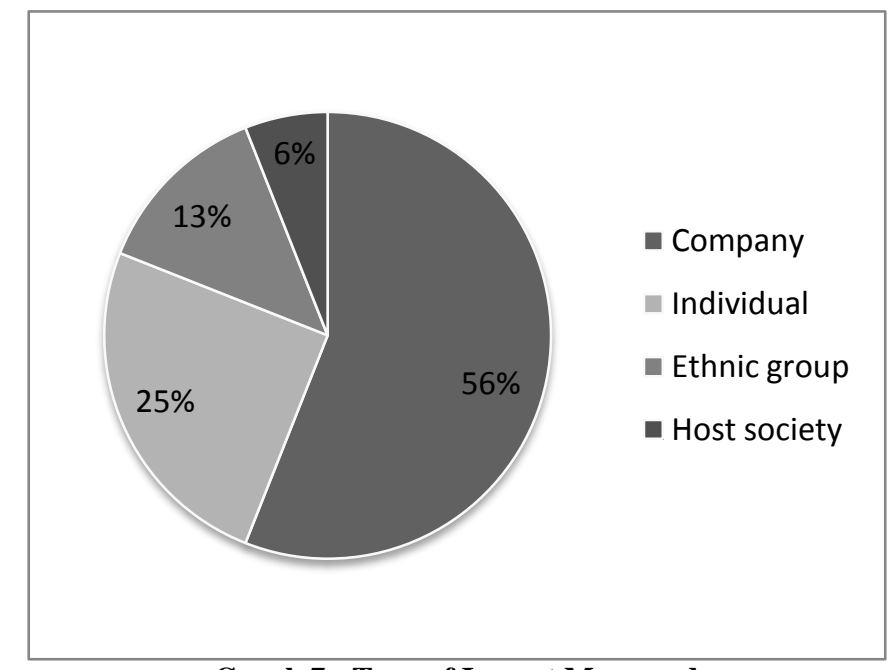

Graph 7: Type of Impact Measured

Indicators of performance are numerous, but their core is very well described by Chrysostome (2010):

"Those indicators can be divided into two major categories: survival indicators, such as the age of the small business and its profitability, and growth indicators. [...] As for the growth indicators, they are evolutionary and 
refer to the increase of various elements such as sales, market share, net profit, and the number of employees. Other growth indicators include return on investment, return on sales, return on assets, and return on cash flow."

Thus, as presented below in Graph 8 and Table 5, growth indicators are the preferred measures for ethnic companies performance (Altinay \& Altinay, 2008; Chaganti, Watts, Chaganti, \& Zimmerman-Treichel, 2008; Dalziel, 2008; Shinnar, Aguilera, \& Lyons, 2011), followed by survival indicators (Chrysostome, 2010; Chrysostome \& Lin, 2010; Fertala, 2007; Sahin, Nijkamp, \& Stough, 2011). A marginal number of articles focus on social indicators such as the economic growth of the host city, the increase of social cohesion, or the improvement of the quality of life thanks to ethnic companies (Eraydin, Tasan-Kok, \& Vranken, 2010). An even smaller number of articles measures performance by referring to elements such as the rate of entrepreneurship in his/her ethnic group or the ethnic entrepreneur's personal satisfaction (Georgarakos \& Tatsiramos, 2009; Masurel, Nijkmamp, Tastan, \& Vindigni, 2002; Wang \& Li, 2007).

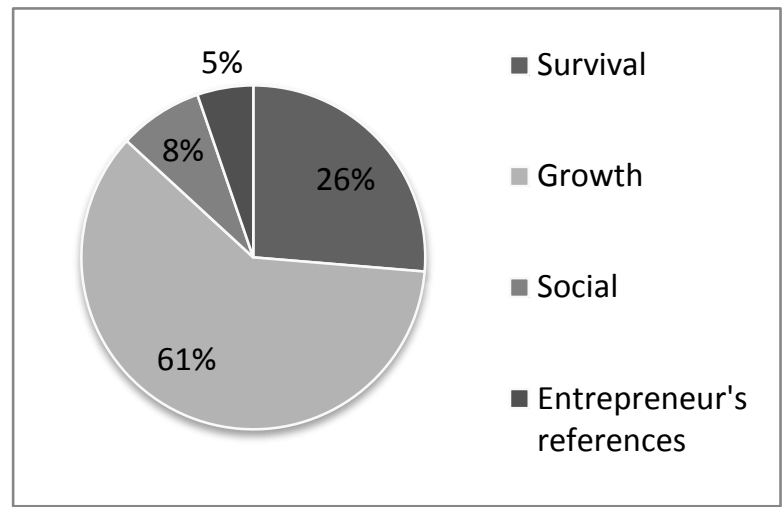

Graph 8: General Indicators of Performance

Table 5: Detailed Indicators of Performance

\begin{tabular}{|c|c|c|c|}
\hline Indicator & Sub-Category & \multicolumn{2}{|c|}{ References } \\
\hline Survival & $\begin{array}{l}\text { Age of the company } \\
\text { Profitability } \\
\text { Productivity } \\
\text { Stability }\end{array}$ & $\begin{array}{l}3 \\
3 \\
2 \\
2 \\
\end{array}$ & 10 \\
\hline Growth & $\begin{array}{l}\text { Sales } \\
\text { Market share } \\
\text { Net profit } \\
\text { Assets } \\
\text { Costs } \\
\text { Number of employees } \\
\text { Salaries of employees } \\
\text { Return on investment } \\
\text { Return on sales } \\
\text { Return on assets } \\
\text { Return on cash flow }\end{array}$ & $\begin{array}{l}7 \\
2 \\
2 \\
1 \\
1 \\
3 \\
2 \\
2 \\
1 \\
1 \\
1\end{array}$ & 23 \\
\hline Social & $\begin{array}{l}\text { Economic growth } \\
\text { Increase of social cohesion } \\
\text { Improvement of the quality of life }\end{array}$ & $\begin{array}{l}1 \\
1 \\
1\end{array}$ & 3 \\
\hline Other references & $\begin{array}{l}\text { Rate of entrepreneurs in ethnic groups } \\
\text { Founder's personal satisfaction }\end{array}$ & $\begin{array}{l}1 \\
1 \\
\end{array}$ & 2 \\
\hline
\end{tabular}

When it comes to measuring performance, most indicators are financial, although these are not accurate for every situation (Chrysostome \& Lin, 2010; Georgarakos \& Tatsiramos, 2009). Hanna, Ebrahim, \& Morino (2011), emphasizing that these indicators "sometimes [...] are too linear and don't capture the complex, total ecosystem challenges", put forward the idea that non-profit indicators at the ecosystem level should be used for future research, such as consideration for stakeholders and relationship building, or learning and capacity building inside the organization. 


\subsection{Social Capital Determinants}

Among the usual determinants of performance for ethnic companies (social capital, economic capital, human capital and context), social capital is the most salient one (29\% of the articles). Literature summarizes social capital within a structural model (Eraydin, Tasan-Kok, \& Vranken, 2010; Kanas, van Tubergen, \& van der Lippe, 2009):

"[...] the first type of social capital is the 'bonding capital' that is created via the strong social ties that exist between individuals, family members, close friends and members of certain ethnic groups. [...] A second type of social capital is 'bridging capital'; the capital that is hidden in the weaker, cross-cutting social ties that exist between heterogeneous individuals, such as 'friends of friends' or neighbors. [...] A third type is 'linking capital', which is characterized by connections between individuals, established professional and administrative structures, and local communities."

Ethnic entrepreneurs use such social capital relationships in order to generate resources (human, financial, information) that are not available internally and thereby facilitate action to develop their company (Bagwell, 2008; Nakhaie, 2009; Ndofor \& Priem, 2011; Piperopoulos, 2010). Simply put, family, friends and personal contacts are channels for entrepreneurs to obtain the means to perform well. Some authors particularly emphasize the importance of the family (Bagwell, 2008; Siqueira, 2007) in this process whereas others focus more on the whole ethnic group (Brenner, Menzies, Dionne, \& Filion, 2010; Dalziel, 2008). Usually, authors use several sub-factors of social capital to determine which one will induce performance. They are presented in Graph 9.

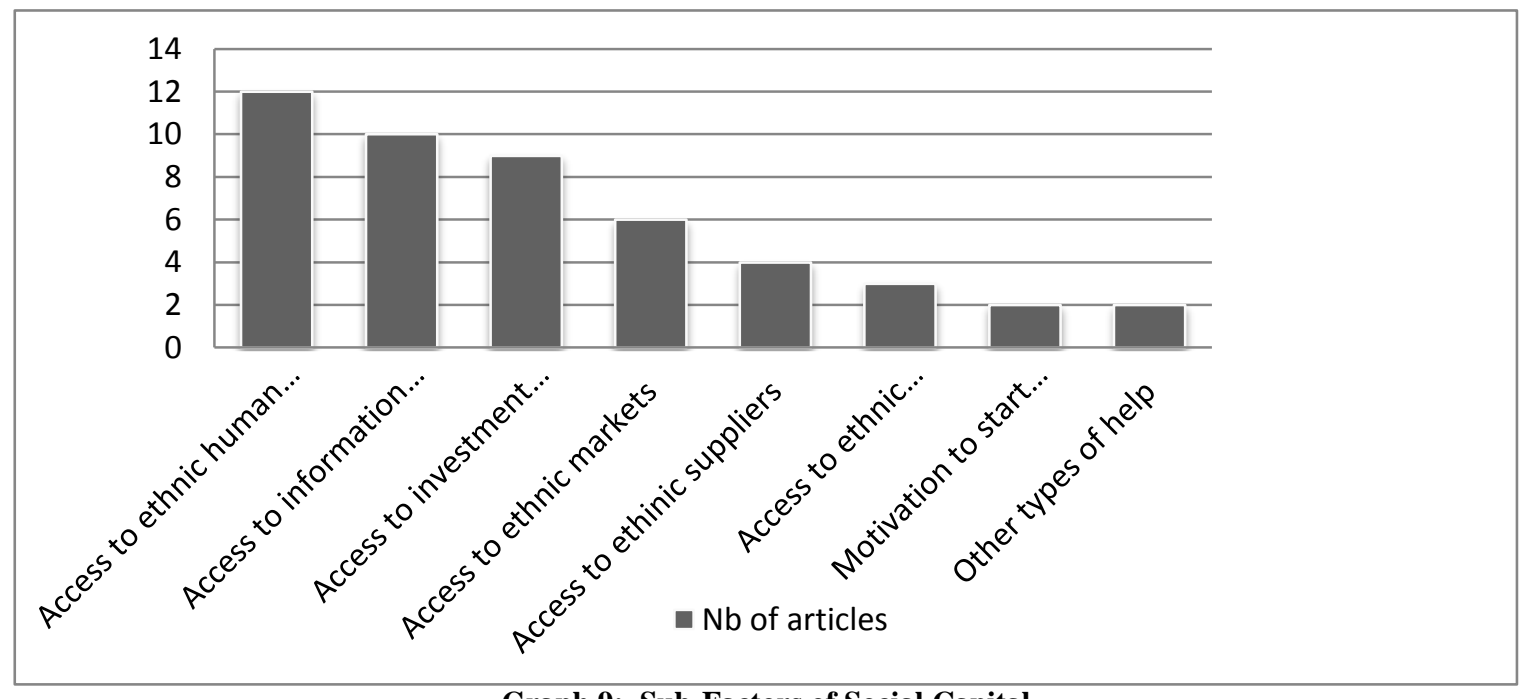

Graph 9: Sub-Factors of Social Capital

Among the sub-factors of social capital, access to human resources is judged critical. Considering that entrepreneurs often don't have many financial reserves, resorting to family or ethnic community is necessary to provide a "vital and reliable source of labor" (Piperopoulos, 2010). Especially, the aspect of benefiting from a highly-committed workforce which will be underpaid or unpaid is determinant (Chand \& Ghorbani, 2011; Kanas, van Tubergen, \& van der Lippe, 2009; Yang, Colarelli, Han, \& Page, 2011). Not surprisingly, the second and third determining elements for ethnic companies are access to information and investment capital. Indeed, ethnic ties result in a comparative advantage for ethnic entrepreneurs since they will benefit from valuable market and business information about opportunities and threats that would otherwise be inaccessible (due to time and resource limitations) (Curci \& Mackoy, 2010; Marger M. N., 2002; Nakhaie, 2009). Similarly, they have easier access to financial capital, with preferred conditions of loan (low interest rates or adjustable duration of repayment) (Altinay \& Altinay, 2008; Piperopoulos, 2010; Siqueira, 2007). Finally, being a member of a specific ethnic group can help penetrate an ethnic market and successfully target customers from that same community, since both entrepreneur and clients will share a common origin, culture, national background or migratory experience (Eraydin, Tasan-Kok, 
\& Vranken, 2010; Sahin, Nijkamp, \& Stough, 2011). Upstream the value chain, the situation also helps to gain access to ethnic suppliers, with trust more easily given and facilitated commercial agreements (Brenner, Menzies, Dionne, \& Filion, 2010; Curci \& Mackoy, 2010). Very specific help can also be granted, such as finding a place to live (Eraydin, Tasan-Kok, \& Vranken, 2010) or gathering multiple entrepreneurs to start up a company (Fertala, 2007).

\subsection{Human Capital Determinants}

Human capital applied to ethnic entrepreneurship doesn't present any different characteristics than when applied to national entrepreneurship. Sahin, Nijkamp, \& Stough (2011) give a broad definition that encompasses most human capital traits found in the literature: "[...] human capital refers to possession of skills, work experience, knowledge and other useful characteristics (e.g., motivational incentives, leadership style, locus of control) that facilitate self-employment. Human capital factors that in recent studies have been found to affect new venture performance include age, gender, ethnicity, education, relevant industry and general management experience". Traits of human capital can be divided into two dimensions, according to the origin of the trait: individually developed or culturally related. Yet traits of each dimension impact many traits of the other dimension. For instance, cultural background, embodied by the trait "ethnicity", will indeed influence at least personality and skills, as we will describe it. Traits of human capital are presented in Graph 10 and will be discussed below.

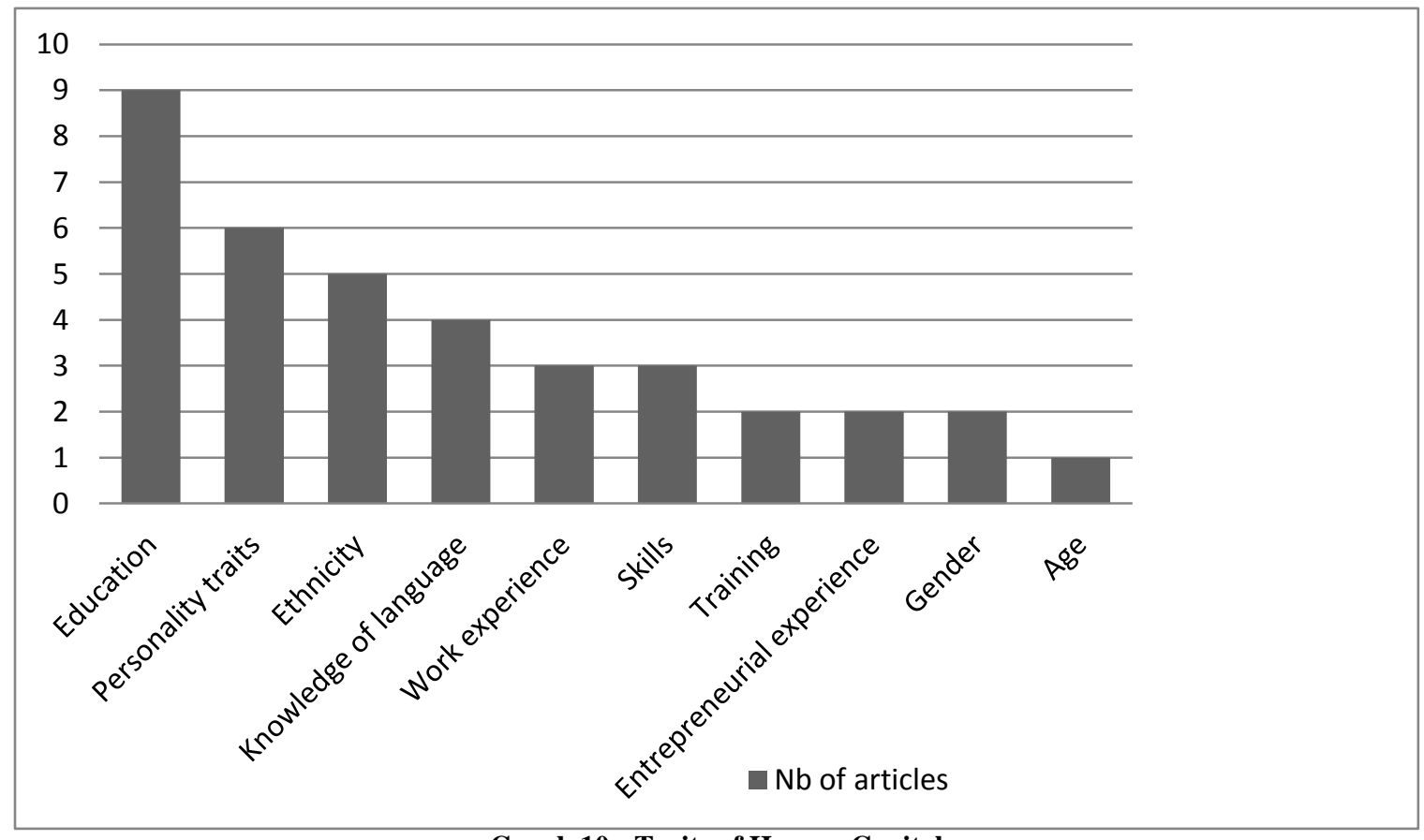

Graph 10: Traits of Human Capital

Education is the most common human capital trait found in the literature. It even happens that educational attainment versus years of schooling serves as a proxy for human capital (Chiang, 2004; Ndofor \& Priem, 2011). Personality traits have a major impact on the survival and performance of the company, a result which is not surprising when it comes to entrepreneurship. The most explored personality traits are need for achievement, propensity for risk-taking, tolerance of ambiguity, locus of control, Autonomy or independence, egoist passion and tenacity and passion (Dalziel, 2008; Sahin, Nijkamp, \& Stough, 2011; Siqueira, 2007; Mohiuddin et al., 2013). Avoidance of uncertainty, for instance, is impacted by ethnicity, as has been shown by Hofstede's cultural dimension theory (Hofstede, 1983). Moreover, it is mainly thanks to their personality traits that ethnic entrepreneurs will overcome the security problems or low purchasing power of unattractive and poorer minority neighborhoods when such neighborhoods represent their co-ethnic market (which are largely ignored by mass retailing businesses) (Piperopoulos, 2010). 
Ethnicity will greatly influence the success of the firm, considering that it will shape special skills, personal motivations, values, attitudes, aspirations for achievement, and heritage of the immigrants (Piperopoulos, 2010). In addition, for the entrepreneur, his/her country of origin can offer a vital source of opportunities, insofar as a great amount of his/her prior knowledge pertains to his/her native country (Bogan \& Darity, 2008; van Gelderen, 2007).

Knowledge of the host country language is also positively correlated to the success of the company, as well as previous work experience, such as basic business practices, or industry and management experience (Curci \& Mackoy, 2010; Sahin, Nijkamp, \& Stough, 2011). Others factors like specific skills (in IT, HR, or finance for example), entrepreneurial experience, gender or age have a minor influence on a business performance. Therefore, authors have seldom chosen to scrutinize them and there are few articles that deal with each.

\subsection{Innovation Determinants}

Innovation, along with creativity, is the last important determinant that can lead to performance, though it has not been studied as thoroughly as the previous ones.

However, innovation is at the core of entrepreneurship, and it resides in every stage of the company's life, from its creation to its strategic development. Innovations scrutinized by researchers are found at three different levels; innovative processes, innovative orientation, innovative products.

Because of a general lack of resources (Altinay \& Altinay, 2008; Chand \& Ghorbani, 2011), ethnic enterprises have to develop new ways of doing business or of promoting themselves so as to be competitive and profitable (Bagwell, 2008; Jamal, 2005). Therefore they may show original operational structures. They can also choose a specific strategic orientation and either focus on a niche market (enclave or ethnic) or evolve from an enclave market to the dominant one (Baycan-Levent, Nijkamp, \& Sahin, 2009; Smallbone, Kitching, \& Athayde, 2010). Finally, because they benefit from information about and knowledge of their ethnic communities' needs, they can tailor products or services to meet those needs (Bagwell, 2008; Ensign \& Robinson, 2011).

The consequences of the three forms of innovation will be felt at different levels as detailed in Graph 11: the whole line of business, the host society, or the company itself.

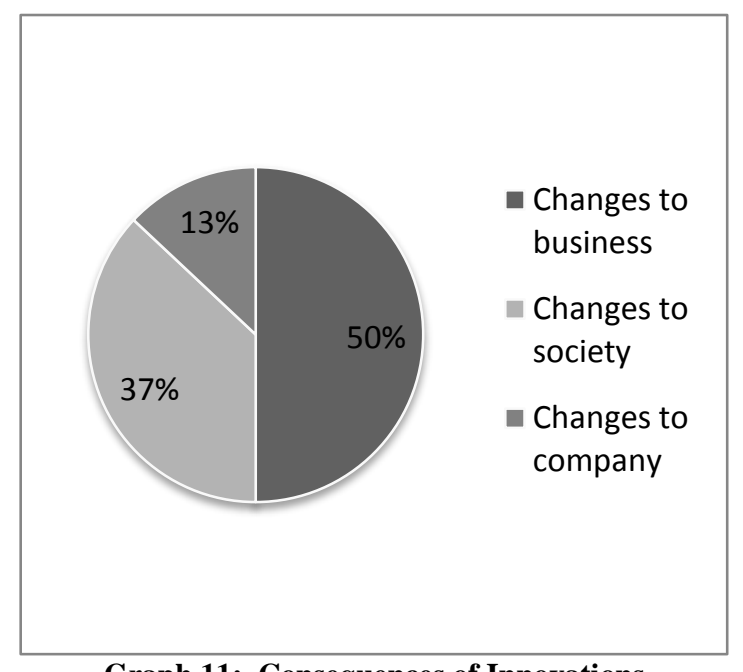

Graph 11: Consequences of Innovations

Innovations mainly bring about changes to the line of business. Introducing new rules, a new player will indeed shape a new environment and, through that disruptive action, will irreversibly change consumer tastes and the nature of the market (Bagwell, 2008; Baycan-Levent, Nijkamp, \& Sahin, 2009; Ensign \& Robinson, 2011; Rahman \& Lian, 2011). Innovative immigrant enterprises will also have an impact on the host society. Namely, they will contribute to the competitiveness of the national economy and to better social integration of immigrants (Ensign 
\& Robinson, 2011; Liu, et al., 2011; Smallbone, Kitching, \& Athayde, 2010). Finally, innovations can sometimes be felt only inside the company, for instance when introducing new strategic practices such as marketing processes (Jamal, 2005).

\subsection{Axiological Determinants}

There is a fifth category of determinants although it is not dealt with in the literature we have studied: axiological determinants. These determinants consist in the moral values that an entrepreneur has acquired through his/her education and his/her life experience. Of course they are related to cultural values and are directly about what is good and what is bad. They are, for instance, integrity, honesty, courage or respect.

The only articles that deal with the impact of axiological determinants on entrepreneurship are those concerned with entrepreneurship in general (usually to the exclusion of its ethnic variant) and with social entrepreneurship. Social entrepreneurs are entrepreneurs with social objective (Martin \& Osberg, 2007) and social entrepreneurship can be defined as the entrepreneurial venture with an embedded social purpose (Austin et al., 2006). The latter is often considered to be an ethical enterprise; as a matter of fact, an academic publication specializing in ethics, the Journal of Business Ethics has devoted no less than 120 papers to social entrepreneurship as of December 2012. However, we have found no article that explores axiological determinants on the success and performance of ethnic for-profit entrepreneurship. In particular, it would be interesting to understand more precisely how the value of loyalty between members of an ethnic group comes into play to reinforce access to economic and social capital. Another interesting research question could link the values of sharing or perseverance to the type of business enterprises favored in a given ethnic community. For instance, we can see the present phenomenon unfolding in the Province of Quebec, Canada: an increasing number of small independent neighborhood groceries are bought and run by Chinese immigrants. Newspaper coverage points to the fact that local aging owners find no one to take over their grocery mainly because of the long hours that have to be put into that type of business. Their children either choose other careers or decide to take over but join a grocery brand in order to benefit from more resources and support. In that instance, decisions from locals to renounce and from Chinese immigrants to buy can be seen as guided by their respective interpretation of the axiological notion of what a "good life" is, of the link between courage and work, or of respect for oneself and a balanced lifestyle.

\section{CONCLUSION AND FUTURE RESEARCH AVENUES}

The precise research objective of this systematic review was to shed light on the current state of the literature on the performance determinants of ethnic companies in OECD countries. We focused on a 10-year period (from the beginning of 2002 to the end of 2011) and gathered a total of 40 articles linked to that very subject which, after analysis, enabled us to highlight both strengths and research gaps on ethnic entrepreneurship and their performance study.

As ethnic entrepreneurship has become a subject of growing interest over this past decade, it was necessary to take time to draw a picture of the research led. So far, none has been conducted specifically on performance determinants of ethnic companies. Of course, we found reviews about international entrepreneurship at large (Jones, Coviello, \& Tang, 2011), or in emerging countries (Kiss, Danis, \& Cavusgil, 2012), and even on specific areas such as entrepreneurship in hospitality and tourism industries ( $\mathrm{Li}, 2008)$.

Hence, there was a need for a first review, in order to draw researchers' attention to the accumulation of articles around some topics (e.g. social and human capital) to the detriment of others (e.g. innovation, host environment, economic capital, axiological determinants). Thanks to this systematic review, we were able to establish the following strengths and lacking of present research trends:

- $\quad$ One of the most important areas for improvement regards performance indicators which are dominated by financial or economic indicators. Authors should also take into consideration qualitative factors to describe the effects of ethnic enterprises, such as their societal impacts or the influence of cultural values on performance. 
- $\quad$ As regards research methodology, researchers often make use of secondary quantitative data in order to put forward hypotheses and conclusions that they do not validate themselves in a different context. We recommend they test their models either on other ethnic communities in the same country or on the same community in another country.

- As for determinants of performance such as social capital or innovation, we found that authors emphasize the cultural influence of his/her ethnic group on the immigrant's way of thinking. Yet they fail to explain clearly which of his/her entrepreneurial decisions it will affect. Therefore further investigation is needed.

- $\quad$ Regarding the choice of a country where to carry out the empirical study, in most cases, only one host country is studied. It is a sound empirical choice since it makes it easier to collect data and explain them. However, analyzing a single ethnic community across multiple countries would offer transnational insights that are rare in the literature so far.

- Symmetrically, when it comes to choosing which ethnic communities to study, researchers will include any immigrant entrepreneur or any ethnic entrepreneur in their sample rather than focus on a particular ethnic group. Indeed, this allows for a better overall comparison of ethnic entrepreneurship in a country. However, it excludes any cultural explanations of certain differences, such as variations in the rate of entrepreneurship across ethnic groups. Hence, we suggest that narrower analyses with only two or three ethnic groups should be provided.

- $\quad$ The growing interest for axiological determinants stemming from the field of business ethics and already showing in the field of social entrepreneurship is not actualized in studies of for-profit ethnic entrepreneurship. Moral values such as loyalty, integrity, sharing or solidarity need to be explored as direct or indirect determinants of performance of ethnic enterprises.

- $\quad$ Another pitfall of the literature regards hypotheses and frameworks of ethnic entrepreneurship. They are generally well supported by ground information from concerned ethnic groups. However, models are narrowed only to those specific groups and are not tested on others that could fit in as well. Hence, transethnic validation could be relevant as a next level of analysis.

- It is limiting that the growing interest of literature about ethnic entrepreneurship is only due to its economic impact on the Gross Domestic Product (GDP) of the host society. Few studies consider the societal impact of such ventures between immigrants and nationals and how such interactions transform the host society. Future research should take an interest in measuring such impact in order for governments to get a holistic picture of those enterprises.

- We may consider as well that the level of analysis is somehow narrowed. Indeed, it has so far been mainly focused on individual actions, those of the entrepreneur - owing to the fact that authors choose small and medium enterprises, which are really linked to the decisions of the owner. However, authors should try to target bigger ethnic businesses to determine what strategic orientations follow from such organizational culture.

- $\quad$ Lastly, considering that ethnic entrepreneurs seem to prefer enclave markets, it could be really worthwhile for future research to consider the conditions of success or willingness to go from an enclave market to the dominant one.

The authors have mainly concentrated their analyses on ethnic entrepreneurs themselves, their culture and their environment, resulting in a strong literature surrounding those aspects. They should now become more interested in adopting a holistic approach to consider the consequences of ethnic entrepreneurship on host societies. Because some authors have already started to study it (Ensign \& Robinson, 2011; Liu, et al., 2011; Smallbone, Kitching, \& Athayde, 2010), we know that ethnic companies can have a positive influence on social integration of immigrants as well as on the host society's economic performance. However, very few indicators have yet been created to describe these consequences, especially when it comes to social integration, which requires more than quantitative measures.

In concentrating their research efforts at that new level of analysis, researchers would be in a position to advise governing bodies on policies to help ethnic entrepreneurship as well as immigration and integration policies. Of course, governing bodies may take direct advantage of the present review to shape those policies. The same is true of chambers of commerce or promotion agencies that could also use our review to adapt their communication strategies toward immigrants. Knowing what community, keen on entrepreneurship, needs which type of attention, such agencies could have a clearer picture of the advice to provide. 
To conclude, we have to emphasize again the importance of ethnic entrepreneurship for OECD countries and the lack of knowledge on some aspects of it (innovation, host environment or economic capital). It is a vital topic nowadays, especially with the aging of the labor force in developed countries, the rise of international migrations and the resulting global challenge of the "war for talents".

\section{AUTHOR INFORMATION}

Maxim Legros completed his MBA from Laval University and has worked as a research assistant. His research interest falls in Entrepreneurship, Social entrepreneurship and high tech entrepreneurs.

Dr. Egide Karuranga is currently Associate professor of International Business and Human Resource management at Faculty of Administrative Sciences, Laval University, Canada. He has numerous papers published in leading journals and won several best paper awards. He has presented his research works in leading international conferences in Management and won "best paper award" at the AOM 2006, ASAC 2006, and ASAC, 2012 conferences. His current research interest falls in Cross-cultural Management, technology and development and Innovation in the emerging countries. E-mail: egide.karuranga@ fsa.ulavel.ca

Dr. Marie-France Lebouc is a professor of management at Laval University. Her area of specialization is business ethics and organizational behavior. She has published several peer reviewed articles and presented her research works in leading international conferences in Management and won "best paper award" at the AGBA, 2013 conference. Her area of interest in research is mainly centred on ethical competencies, ethical judgment, ethics in intercultural situations and entrepreneurship. E-mail: Marie-France.Lebouc@fsa.ulaval.ca

Muhammad Mohiuddin, MBA, DESA, is a $\mathrm{PhD}$ candidate in International Management at the Faculty of Administrative Sciences, Laval University, Canada. His research interests are focused on the emerging markets, sustainable offshore outsourcing and social entrepreneurship. He has presented his research works in leading international conferences in Management and won "best paper award" at the ASAC, 2012 and AGBA, 2013 conferences. He has also published several articles in peer-reviewed journals. His academic and research excellences enabled him to get the award from the CIRRELT, FQRSC, SSHRC, ISESCO and Dean's Award. He teaches courses on "International Management" and "Principles of International Management" at Laval University, Canada. E-mail: muhammad.mohiuddin.1@ulaval.ca (Corresponding author)

\section{REFERENCES}

1. Altan, C. (2007). Turkish immigrants are among 'biggest benefit claimants'. Londra Gazete, 4 (October).

2. Altinay, L., \& Altinay, E. (2008). Factors influencing business growth: the rise of Turkish entrepreneurship in the UK. International Journal of Entrepreneurial Behaviour \& Research, 14(1), 24-46.

3. Assudani, R. H. (2009). Ethnic entrepreneurship: The distinct role of ties. Journal of Small Business and Entrepreneurship, 22(2), 197-206.

4. Bagwell, S. (2008). Transnational family networks and ethnic minority business development: The case of Vietnamese nail-shops in the UK. International Journal of Entrepreneurial Behaviour \& Research, 14(6), 377-394.

5. Baycan-Levent, T., Nijkamp, P., \& Sahin, M. (2009). New orientations in ethnic entrepreneurship: motivation, goals and strategies of new generation ethnic entrepreneurs. International Journal of Foresight and Innovation Policy, 5(1-3), 83-112.

6. Berg, N., \& Holtbrügge, D. (2010). Global teams: a network analysis. Team Performance Management, 16(3/4), 187-211.

7. Bogan, V., \& Darity, W. J. (2008). Culture and entrepreneurship? African American and immigrant selfemployment in the United States. Journal of Socio-Economics, 37(5), 1999-2019.

8. $\quad$ Brenner, G. A., Menzies, T. V., Dionne, L., \& Filion, L. J. (2010). How location and ethnicity affect ethnic entrepreneurs in three Canadian cities. Thunderbird International Business Review, 52(2), 153-171.

9. Chaganti, R. S., Watts, A. D., Chaganti, R., \& Zimmerman-Treichel, M. (2008). Ethnic immigrants in founding teams: Effects on prospector strategy and performance in new Internet ventures. Journal of Business Venturing, 23(1), 113-139. 
10. Chand, M., \& Ghorbani, M. (2011). National culture, networks and ethnic entrepreneurship: A comparison of the Indian and Chinese immigrants in the US. International Business Review, 20(6), 593-606.

11. Chiang, L.-H. N. (2004). The dynamics of self-employment and ethnic business ownership among Taiwanese in Australia. International Migration, 42(2), 153-173.

12. Chrysostome, E. (2010). The success factors of necessity immigrant entrepreneurs: In search of a model. Thunderbird International Business Review, 52(2), 137-152.

13. Chrysostome, E., \& Lin, X. (2010). Immigrant entrepreneurship: Scrutinizing a promising type of business venture. Thunderbird International Business Review, 52(2), 77-82.

14. Clarke, J., \& Holt, R. (2010). Reflective Judgement: Understanding Entrepreneurship as Ethical Practice. Journal of Business Ethics, 94(3), 317-331.

15. Constant, A. F. (2009). Businesswomen in Germany and their performance by ethnicity: It pays to be selfemployed. International Journal of Manpower, 30(1-2), 145-162.

16. Constant, A., \& Shachmurove, Y. (2006). Entrepreneurial ventures and wage differentials between Germans and immigrants. International Journal of Manpower, 27(3), 208- 229.

17. Curci, R., \& Mackoy, R. (2010). Immigrant business enterprises: A classification framework conceptualization and test. Thunderbird International Business Review, 52(2), 107-121.

18. Dai, F., Wang, K. Y., \& Teo, S. T. (2011). Chinese immigrants in network marketing business in Western host country context. International Business Review, 20(6), 659-669.

19. Dalziel, M. (2008). Immigrants as Extraordinarily Successful Entrepreneurs: A Pilot Study of the Canadian Experience. Journal of Small Business and Entrepreneurship, 21(1), 23-36.

20. Ensign, P. C., \& Robinson, N. P. (2011). Entrepreneurs because they are Immigrants or Immigrants because they are Entrepreneurs? A Critical Examination of the Relationship between the Newcomers and the Establishment. The Journal of Entrepreneurship, 20(1), 33-53.

21. Eraydin, A., Tasan-Kok, T., \& Vranken, J. (2010). Diversity Matters: Immigrant Entrepreneurship and Contribution of Different Forms of Social Integration in Economic Performance of Cities. European Planning Studies, 18(4), 521-543.

22. Fainstein, S. S. (2005). Cities and diversity: Should we want it? Can we plan for it? Urban Affairs Review, 4l(1), 3-19.

23. Fertala, N. (2007). A study of immigrant entrepreneurship in Upper Bavaria. International Journal of Entrepreneurship and Small Business, 4(2), 179-206.

24. Fisscher, O., Frenkel, D., Lurie, Y., \& Nijhof, A. (2005). Stretching the Frontiers: Exploring the Relationships Between Entrepreneurship and Ethics. Journal of Business Ethics, 60(3), 207-209.

25. Georgarakos, D., \& Tatsiramos, K. (2009). Entrepreneurship and survival dynamics of immigrants to the U.S. and their descendants. Labour Economics, 16(2), 191-170.

26. Hanna, J., Ebrahim, A. S., \& Morino, M. (2011). The New Measures for Improving Non-profit Performance. Harvard Business School Working Knowledge. December, 14. http://hbswk.hbs.edu/item/6825.html. Accessed 2013-05-03.

27. Hart, D. M., \& Acs, Z. J. (2011). High-Tech Immigrant Entrepreneurship in the United States. Economic Development Quarterly, 25(2), 116-129.

28. Hofstede, G. (1983). National cultures in four dimensions: A research-based theory of cultural differences among nations. International Studies of Management \& Organization, 13(1-2), 46-74.

29. Ibrahima, G., \& Galtb, V. (2011). Explaining ethnic entrepreneurship: An evolutionary economics approach. International Business Review, 20(6), 607-613

30. Jamal, A. (2005). Playing to win: an explorative study of marketing strategies of small ethnic retail entrepreneurs in the UK. Journal of Retailing and Consumer Services, 12(1), 1-13.

31. Jeana, R.-J. B., Tana, D., \& Sinkovicsb, R. R. (2011). Ethnic ties, location choice, and firm performance in foreign direct investment: A study of Taiwanese business groups FDI in China. International Business Review, 20(6), 627-635.

32. Jones, M. V., Coviello, N., \& Tang, Y. K. (2011). International Entrepreneurship research (1989-2009): A domain ontology and thematic analysis. Journal of Business Venturing, 26(6), 632 - 659.

33. Kanas, A., van Tubergen, F., \& van der Lippe, T. (2009). Immigrant Self-Employment: Testing Hypotheses About the Role of Origin- and Host-Country Human Capital and Bonding and Bridging Social Capital. Work and Occupations, 36(3), 181-208. 
34. Kiss, A. N., Danis, W. M., \& Cavusgil, S. T. (2012). International entrepreneurship research in emerging economies: A critical review and research agenda. Journal of Business Venturing, 27(2), 266 - 290.

35. Kitchenham, B. (2004). Procedures for Performing Systematic Reviews. Keele University Technical Report TR/SE 04-01. Newcastle-under-Lyme. Keele University.

36. Lerner, M., Menahem, G., \& Hisrich, R. D. (2005). Does government matter? The impact of occupational retraining, gender and ethnicity on immigrants' incorporation. Journal of Small Business and Enterprise Development, 12(2), 192-210.

37. Li, L. (2008). A review of entrepreneurship research published in the hospitality and tourism management journals. Tourism Management, 29(5), 1013 - 1022.

38. Liu, X., Lu, J., Filatotchev, I., Buck, T., Wright, M., McPherson, M., Egorov, I. (2011). Entrepreneurship and innovation in a cultural framework. Strategic Direction, 27(6), 29-31.

39. Malina, MA. (2013). The Evolution Of A Balanced Scorecard. Journal of Applied Business Research, 29(3), 901-912. Access on $15^{\text {th }}$ May, 2013:

http://journals.cluteonline.com/index.php/JABR/article/view/7790

40. Marger, M. (2001). The use of social and human capital among Canadian business immigrants. Journal of Ethnic and Migration Studies, 27(3), 439-453.

41. Marger, M. N. (2002). Social and human capital in immigrant adaptation: The case of Canadian business immigrants. Journal of Socio-Economics, 30(2), 169-170.

42. Masurel, E., Nijkmamp, P., Tastan, M., \& Vindigni, G. (2002). Motivations and performance conditions for ethnic entrepreneurship. Growth and Change, 33(2), 238-260.

43. McKinsey \& Company. (2001). The War for Talent; Organization and Leadership Practice. New York: McKinsey \& Company, Inc.

44. Mohiuddin, M. \& Su, Z. (forthcoming, 2014). Outsourcing Core and Non-Core Activities and Integrated Firm Level Performance (IFLP): An Empirical Analysis on Quebec Manufacturing Outsourcing.

45. Mohiuddin, M., Parveen, R, Rahman, MI. \& Mazumder, MNH. (2013). Entrepreneurial Motivation and Social Enterprises: An Empirical Analysis on Founders of Social Ventures in Bangladesh, Transnational Corporation Review, 5(2), 77-92. http://dx.doi.org/10.5148/tncr.2013.5206

46. Mohiuddin, M. (2011). Research on Offshore outsourcing: A systematic literature review. Journal of International Business Research (JIBR), 10(1), 57-76.

47. Nakhaie, M. R. (2009). Immigrants, Visible Minorities and Self-employment: Does Social Capital Make a Difference? The Business Review, 13(1), 80-86.

48. Ndofor, H. A., \& Priem, R. L. (2011). Immigrant Entrepreneurs, the Ethnic Enclave Strategy, and Venture Performance. Journal of Management, 37(3), 790-818.

49. OECD. (2008). The Global Competition for Talent: Mobility of the highly skilled. Washington: OECD Publishing.

50. Ostergaard, C. R., Timmermans, B., \& Kristinsson, K. (2011). Does a different view create something new? The effect of employee diversity on innovation. Research Policy, 40(3), 500-509.

51. Payne, D., \& Joyner, B. (2006). Successful U.S. Entrepreneurs: Identifying Ethical Decision-making and Social Responsibility Behaviors. Journal of Business Ethics, 65(3), 203-217.

52. Piperopoulos, P. (2010). Ethnic minority businesses and immigrant entrepreneurship in Greece. Journal of Small Business and Enterprise Development, 17(1), 139-158.

53. Rahman, M. M., \& Lian, K. F. (2011). The Development of Migrant Entrepreneurship in Japan: Case of Bangladeshis. Journal of International Migration and Integration, 12(3), 253-274.

54. Roberge, M.-É., \& van Dick, R. (2010). Recognizing the benefits of diversity: When and how does diversity increase group performance? Human Resource Management Review, 20(4), 295-308.

55. Royal Society. (1963). "Emigration of Scientists from the UK," Report of the Committee Appointed by the Council of the Royal Society. London: The Royal Society of London for Improving Natural Knowledge.

56. Sahin, M., Nijkamp, P., \& Stough, R. (2011). Impact of urban conditions on firm performance of migrant entrepreneurs: a comparative Dutch-US study. The Annals of Regional Science, 46(3), 661-689.

57. Shinnar, R. S., Aguilera, M. B., \& Lyons, T. S. (2011). Co-ethnic markets: Financial penalty or opportunity? International Business Review, 20(6), 646-658.

58. Siqueira, A. C. (2007). Entrepreneurship and ethnicity: the role of human capital and family social capital. Journal of Developmental Entrepreneurship, 12(1), 31-46. 
59. Slater, S. F., Weigand, R. A., \& Zwirlein, T. J. (2008). The business case for commitment to diversity. Business Horizons, 51(3), 201-209.

60. Smallbone, D., Kitching, J., \& Athayde, R. (2010). Ethnic diversity, entrepreneurship and competitiveness in a global city. International Small Business Journal, 28(2), 174-190.

61. Staples, M., \& Niazi, M. (2007). Experiences using systematic review guidelines. Journal of Systems and Software, 80(9), 1425-1437.

62. Sultana, M.A., Rashid, M.M., Mohiuddin, M., \& Mazumder, MNH. (2013). Cross-cultural Management and Organizational Performance: A Content Analysis Perspective. International Journal of Business and Management, 8(8):113-146. http://dx.doi.org/10.5539/ijbm.v8n8p133

63. Taylor, D., \& Procter, M. (2008). The literature review: a few tips on conducting it. Toronto: University of Toronto.

64. Tranfield, D., Denyer, D., \& Smart, P. (2003). Towards a Methodology for Developing Evidence-Informed Management Knowledge by Means of Systematic Review. British Journal of Management, 14, $207-222$.

65. United Nations. (2002). World Population Ageing: 1950-2050. New York: United Nations Department of Economic and Social Affairs.

66. United States Census Bureau. (2010). Census Bureau reports minority business ownership increasing at more than twice the national rate. Press release, July, 13. US Department of Commerce. http://www.census.gov/newsroom/releases/archives/economic census/cb10-107.html. Accessed 2013-05$\underline{03}$

67. Van Gelderen, M. (2007). Country of origin as a source of business opportunities. International Journal of Entrepreneurship and Small Business, 4(4), 419-430.

68. Wang, Q., \& Li, W. (2007). Entrepreneurship, ethnicity and local contexts: Hispanic entrepreneurs in three U.S. southern metropolitan areas. GeoJournal, 68(2-3), 167-182.

69. Yang, C., Colarelli, S. M., Han, K., \& Page, R. (2011). Start-up and hiring practices of immigrant entrepreneurs: An empirical study from an evolutionary psychological perspective. International Business Review, 20(6), 636-645. 